\title{
Erratum zu: Unternehmensstrategie - treffend verpackt
}

\section{Über 800 Zitate ausgewählter Persönlichkeiten}

\section{Erratum zu:}

Springer Fachmedien Wiesbaden GmbH (Hrsg.), Unternehmensstrategie - treffend verpackt, https://doi.org/10.1007/978-3-658-31675-4

Ein technischer Fehler im Produktionsablauf hat dazu geführt, dass das Buch zunächst mit 2021 als Copyright Jahr veröffentlicht wurde. Das Copyright Jahr ist 2020. Dies wurde nachträglich korrigiert. 